\title{
PERANCANGAN SISTEM PENGADAAN PENJUALAN ALAT KESEHATAN PADA PT. TRISNA WIRATAMA BERBASIS JAVA
}

\author{
Nadiah Handayani $^{1}$, Meri Chrismes Aruan ${ }^{2}$, Nurmala Dewi Qadarsih ${ }^{3}$ \\ 1, 2,3 Universitas Indraprasta PGRI \\ Jalan Raya Tengah, Gedong, Pasar Rebo, Jakarta Timur, Daerah Khusus Ibukota Jakarta 13760 \\ ${ }^{1}$ nadiahhandayani8@gmail.com, ${ }^{2}$ meriprincess08aruan@gmail.com, ${ }^{3}$ dwie.noer78@gmail.com
}

\begin{abstract}
ABSTRAK
Peningkatan inovasi yang cepat sesekali membuat pekerjaan yang dilakukan oleh orang secara keseluruhan dapat diselesaikan dengan cepat, jumlah perusahaan berkembang dan terus melakukan upaya dan sistem untuk mengikuti bisnis mereka, keberhasilan perusahaan dalam menjalankan bisnisnya tidak lepas dari peran perusahaan dalam menangani perolehan dan transaksi barang dagangan. Tujuan adanya penelitian ini ialah untuk merancang aplikasi menggunakan NetBeans Java yang digunakan untuk mengolah data pada PT. Trisna Wiratama seperti penginputan barang masuk, penginputan barang keluar, penginputan stok barang, penginputan supplier, dan laporan-laporan seperti laporan data admin, laporan data supplier, laporan data stok barang, laporan data pembelian dan penjualan. Metode penelitian yang digunakan adalah metode penelitian deskriptif, artinya data yang dikumpulkan bukan berupa data numerik, melainkan data yang diperoleh dari wawancara, catatan lapangan, dokumen pribadi, atau dokumen resmi pendukung lainnya. Hasil yang didapat dari pengunaan aplikasi ini adalah mempermudah karyawan perusahaan dalam mengolah dan menyimpan datadata tersebut karena data-data tersebut telah tersimpan di dalam database MySQL dengan aman.
\end{abstract}

Kata Kunci: Perancangan Sistem, Informasi, Pengadaan, Penjualan, Java

\begin{abstract}
The rapid increase in innovation occasionally makes the work done by people as a whole can be completed quickly, the number of companies is growing and continues to make efforts and systems to keep up with their business, the company's success in running its business cannot be separated from the company's role in handling the acquisition and transaction of merchandise. The purpose of this research is to design an application using NetBeans Java which is used to process data at PT. Trisna Wiratama such as inputting incoming goods, inputting goods out, inputting stock of goods, inputting suppliers, and reports such as admin data reports, supplier data reports, stock data reports, purchase and sales data reports. The research method used is descriptive research method, meaning that the data collected is not in the form of numerical data, but data obtained from interviews, field notes, personal documents, or other supporting official documents. The results obtained from the use of this application are to make it easier for company employees to process and store these data because the data has been stored in the MySQL database safely.
\end{abstract}

Key Word: System Design, Information, Procurement, Sales, Java

\section{PENDAHULUAN}

Pengadaan dan penjualan barang didalam suatu usaha menjadi penting bagi suatu perusahaan, karena dari pengadaan dan penjualan tersebut kita bisa mengetahui dari mana saja barang tersebut dibeli dan dijual sehingga mempermudah jika akan membeli dan menjual kembali barang tersebut. Penulis melakukan penelitian terhadap cara kerja karyawan PT. Trisna Wiratama dan ditemukan hasil-hasil yang tidak akurat seperti kesalahan dalam pencatatan hari dan tanggal serta hilangnya data yang tersimpan hanya di dalam buku besar. Tujuan dari Perancangan Sistem Informasi Pengadaan Dan Penjualan Alat Kesehatan Pada PT.
Trisna Wiratama dibuat untuk memudahkan para karyawan dalam mendata pengadaan barang dan penjualan barang. Serta manfaat dari adanya penelitian ini diharapkan dapat membantu penggunanya dalam pendataan serta laporan kegiatan dengan lebih cepat, efektif, efisien dan akurat.

Sistem adalah sekumpulan unsur atau elemen yang saling terkait dan saling mempengaruhi dalam melakukan kegiatan bersama untuk dapat mencapai suatu tujuan. (Suprihadi, 2013:310). Sistem Informasi merupakan "Seperangkat fungsi operasional manajemen kepada yang mampu menghasikan suatu keputusan yang tepat, cepat dan jelas sehingga 
menjadi suatu susunan yang disusun secara sistematik dan teratur". (Aswati dkk, 2015). Sistem Informasi adalah kumpulan dari subsub sistem yang saling terintegrasi dan berkolaborasi untuk menyelesaikan masalah tertentu dengan cara mengolah data dengan alat yang bernama komputer sehingga memiliki nilai tambah dan bermanfaat bagi pengguna". (Taufiq, 2013:17). Pengadaan barang dan jasa didasarkan pada metode dan prosedur pengadaan standar, sesuai dengan norma dan etika populer, dan atas dasar logika dan pemikiran sistematis (sistem ideologis), upaya untuk mendapatkan barang dan jasa yang dibutuhkan (Menurut Marbun, 2010 yang dikutip oleh Tenri Maharani Unra 2015). Penjualan adalah pemindahan hak milik atas barang atau pemberian jasa yang dilakukan penjual kepada pembeli dengan harga yang telah disepakati. (Islamiyah, 2018). Saat ini, hampir tidak mungkin memberikan pelayanan kesehatan tanpa alat kesehatan. Mengingat ketersediaan alat kesehatan begitu penting dalam upaya pelayanan kesehatan, maka perlu adanya manajemen 3 logistik alat kesehatan untuk menjaga kualitas dalam jumlah yang sesuai dengan memperhatikan standar sesuai dengan klasifikasi (Faruq dkk, 2017).

Perancangan sistem informasi pengadaan dan penjualan alat kesehatan pada PT. Trisna Wiratama ini dibangun dengan bahasa pemrograman Java dan menggunakan database MySQL. Database adalah sekumpulan data store (bisa dalam jumlah yang sangat besar) yang tersimpan dalam magnetic disk, official disk, magnetic drum, atau media penyimpanan sekunder lainnya. (Ladjamudin, 2013:129). Netbeans Merupakan Sebuah aplikasi Integrated Development Environment (IDE) yang Menggunakan Bahasa Pemograman Java dari Sun Microsystems yang berjalan diatas swing". (Nofriadi, 2015:4) Java adalah bahasa pemrograman yang berorientasi objek (OOP) dan dapat dijalankan pada berbagai platfrom sistem operasi. (Indarianto, 2013).

\section{METODE PENELITIAN}

Peneliti menggunakan pendekatan deskriptif, artinya data yang dikumpulkan bukan berupa data numerik, melainkan data yang diperoleh dari wawancara, catatan lapangan, dokumen pribadi, atau dokumen resmi pendukung lainnya. Seperti yang telah dijelaskan di atas, penelitian ini akan menggunakan studi kasus. Strategi yang digunakan untuk berbagai informasi dalam tinjauan ini, antara lain:

1. Observasi

Tahap ini merupakan tahap melakukan pengamatan langsung terhadap pengguna sistem dan pengamatan langsung terhadap sistem yang sedang berjalan di PT. Trisna Wiratama.

2. Wawancara

Pada tahap ini peneliti melakukan wawancara dengan kepala perusahaan dan bagian admin sebagai pengguna sistem manual yang sedang berjalan untuk mendapatkan informasi mengenai data pasien. Wawancara ini dilakukan pada admin PT. Trisna Wiratama.

3. Dokumentasi

Pengumpulan data yang dilakukan dengan mengamati dokumen-dokumen PT.Trisna Wiratama yang berkaitan dengan sitem informasi yang dibangun.

Adapun untuk sistem perancangan penulis menggunakan :

1. Dekomposisis sistem kerangka kerja ini memudahkan pemeriksa dan arsitek kerangka kerja untuk melihat dan menilai kerangka kerja yang rumit dan kompleks.

2. UML (Brought Together Displaying Language) adalah bahasa yang bergantung pada desain/gambar untuk membayangkan, menentukan, merakit, dan merekam kerangka pengembangan produk yang bergantung pada OO (Item Arranged).

3. Grafik Use Case adalah pengelompokan koneksi yang saling terkait antara framework dan entertainer. Use case dieksekusi dengan menggambarkan jenis koneksi antara klien dari suatu program (framework) dan framework yang sebenarnya. Gunakan kasus melalui cerita di mana kerangka kerja digunakan

4. Class chart adalah visual dari perancangan program framework pada macam-macam yang dibentuk. Bagan kelas adalah perkembangan kumpulan data pada kerangka kerja.

Ruang Lingkup yang dibahas disini ialah proses pengadaan dan penjualan alat kesehatan pada PT. Trisna Wiratama. Penulis hanya berfokus pada masalah proses penginputan barang masuk, penginputan 
barang keluar, penginputan stok barang, penginputan supplier, dan laporan-laporan seperti laporan data admin, laporan data supplier, laporan data stok barang, laporan data pembelian dan penjualan.

\section{HASIL DAN PEMBAHASAN}

Hasil dari penelitian pada PT. Trisna Wiratama nantinya akan dirancang sebuah sistem pengadaan dan penjualan gar memudahkan dalam pendataan barang masuk, barang keluar, pendataan stok barang dan penyimpanan data. Karna sistem yang berjalan untuk saat ini belum terkomputerisasi masih terdapat permasalahan seperti pada pengadaan barang dan penjualan barang ini masih melakukan sistem yang manual seperti harus mencatat di sebuah buku catatan dan hal tersebut memakan waktu yang cukup banyak. Hal tersebut dapat mengakibatkan banyak kesalahan dan kurang efisien untuk sebuah perusahaan.

Langkah-langkah dalam perancangan sistem informasi yang diusulkan :

Dekomposisi sistem yang diusulkan

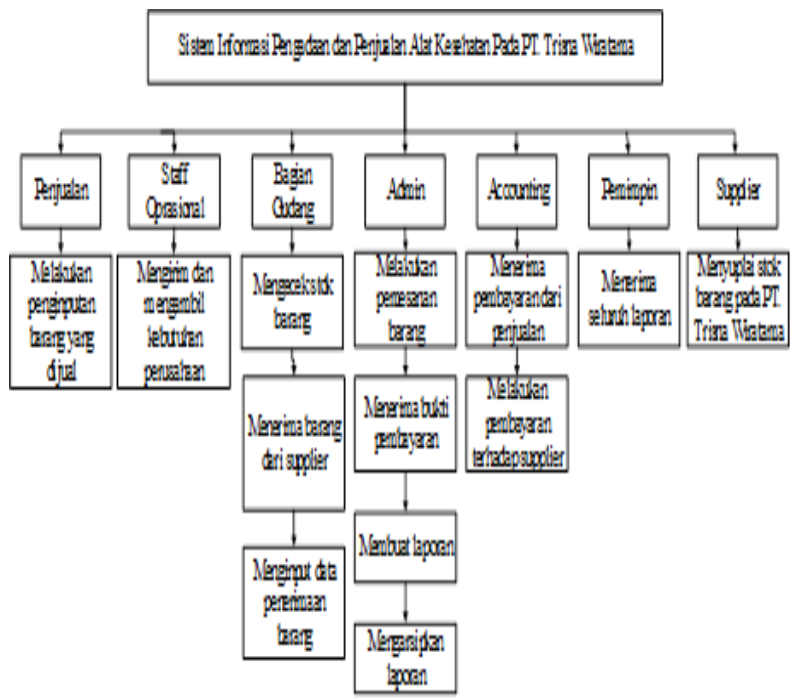

Gambar 1. Diagram Konteks yang Diusulkan

Setelah membuat dekomposisi fungsi sistem maka selanjutnya membuat UML sistem yang diusulkan.

Unifed Modelling language (UML) Sistem yang diusulkan

\section{Use Case}

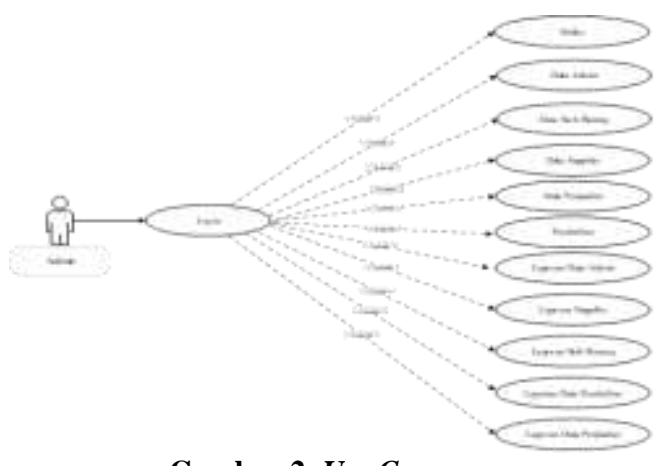

Gambar 2. Use Case

Sistem ini memungkinkan karyawan perusahaan untuk mengakses aplikasi pengadaan dan penjualan alat kesehatan.

\section{Class Diagram}

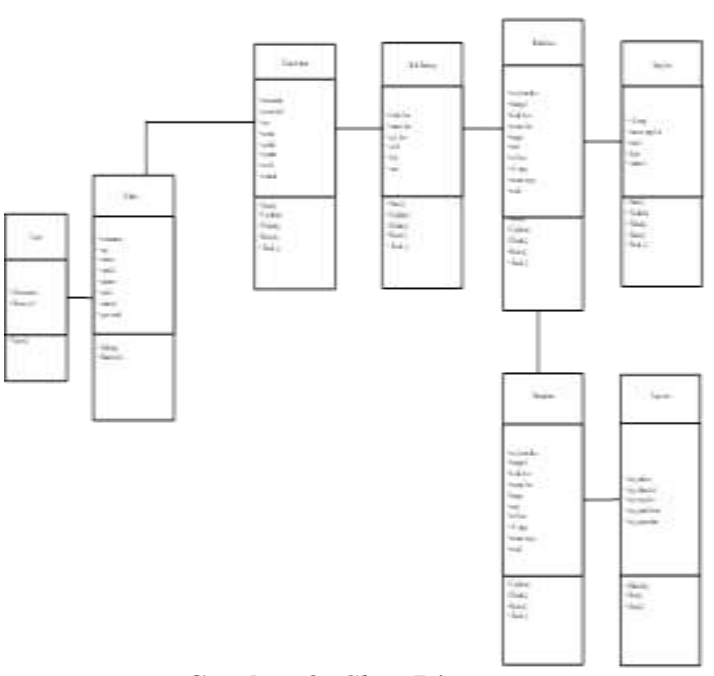

Gambar 3. Class Diagram

Class diagram ini diguanakan untuk melihat alur jalannya database pada sebuah sistem pengadaan dan penjualan alat kesehatan.

\section{Tampilan Layar (User Interface)}

Tampilan Menu Login

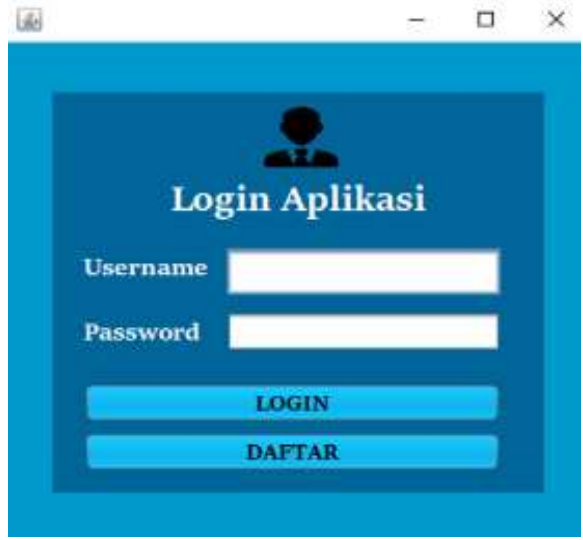

Gambar 4. Tampilan Layar Login 
Pada menu login terdapat username dan password yang digunakan untuk akses Sistem Pengadaan Dan Penjualan Alat Kesehatan Pada PT. Trisna Wiratama.

Tampilan Daftar

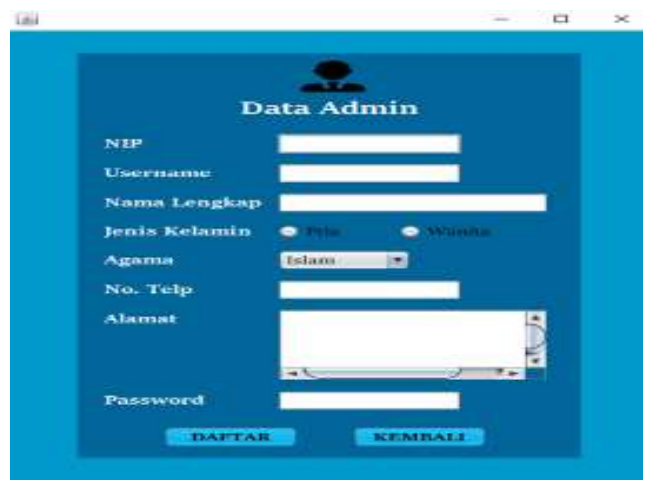

Gambar 5. Tampilan Layar Daftar

Pada fotm daftar ini digunakan untuk menginput data admin.

Tampilan Menu Utama

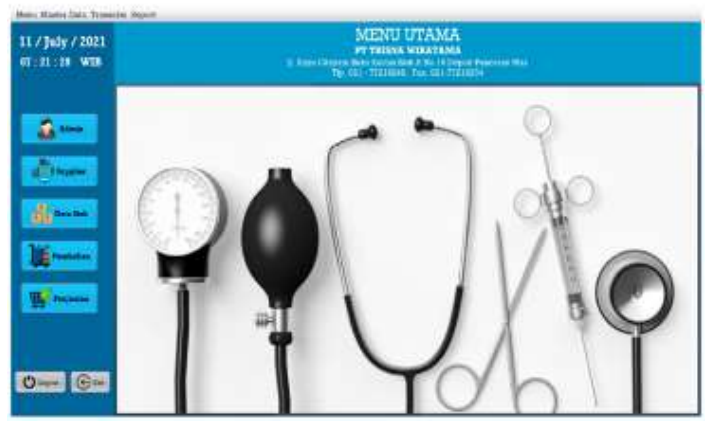

Gambar 6. Tampilan Layar Menu Utama

Pada tampilan menu utama terdapat beberapa menu yaitu Menu data admin, data supplier, data stok barang, data pembelian, penjualan dan menu laporan

Tampilan Data Admin

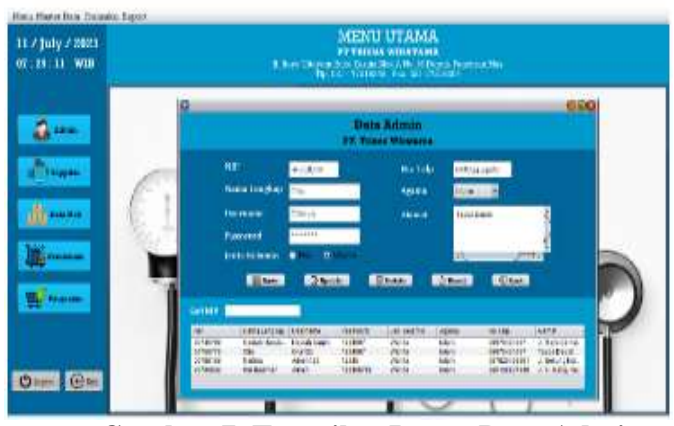

Gambar 7. Tampilan Layar Data Admin

Pada form data admin ini digunakan untuk menginput dan menyimpan data admin serta dapat mengapus, mengubah dan mencari data yang diinginkan.

Tampilan Data Supplier

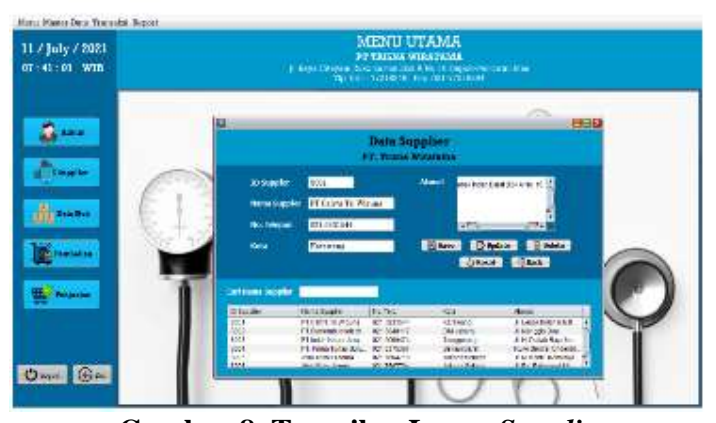

Gambar 8. Tampilan Layar Supplier

Pada form data supplier ini digunakan untuk menginput dan menyimpan data supplier serta dapat mengapus, mengubah dan mencari data yang diinginkan.

Tampilan Data Stok Barang

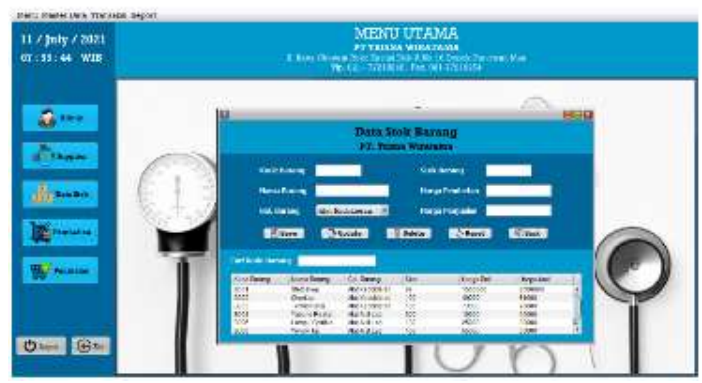

Gambar 9. Tampilan Layar Data Stok Barang

Pada form data stok barang ini digunakan untuk menginput dan menyimpan data stok barang serta dapat mengapus, mengubah dan mencari data yang diinginkan.

Tampilan Data Pembelian

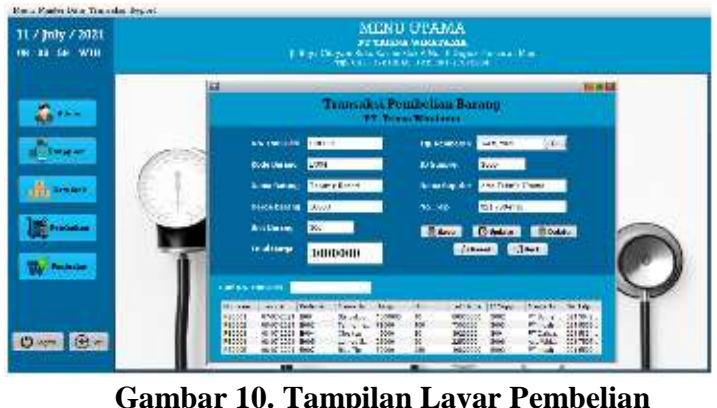

Pada form pembelian ini digunakan untuk menginput dan menyimpan data pembelian serta dapat menghapus, mengubah dan mencari data yang diinginkan. 
Tampilan Data Penjualan

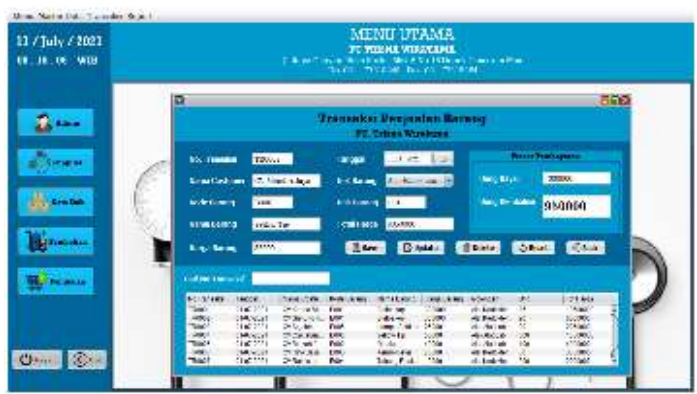

Gambar 11. Tampilan Layar Penjualan

Pada form penjualan ini digunakan untuk menginput dan menyimpan data penjualan serta dapat mengapus, mengubah dan mencari data yang diinginkan.

Tampilan Laporan Data Admin

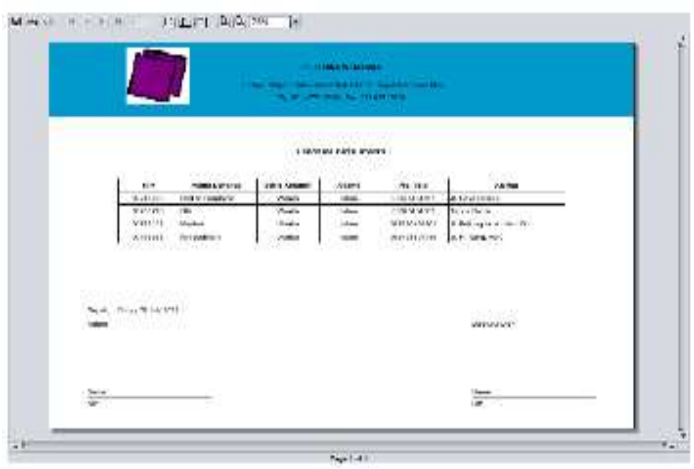

Gambar 12. Tampilan Layar Laporan Data Admin

Gambar tersebut merupakan tampilan laporan data admin.

Tampilan Lapoaran Data Supllier

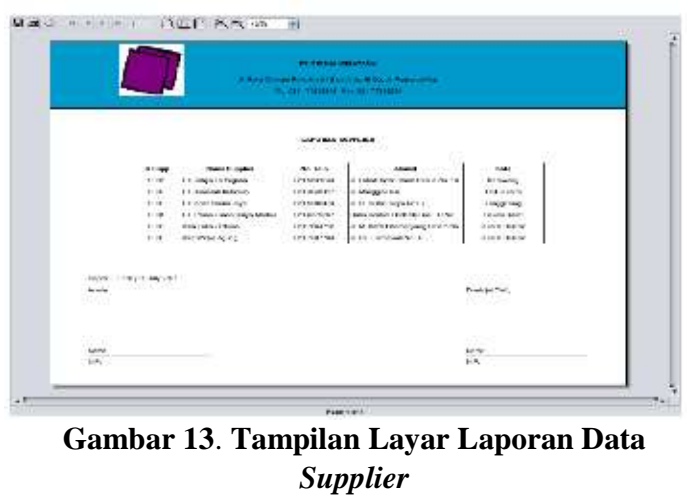

Gambar tersebut merupakan tampilan laporan data supplier
Tampilan Laporan Data Stok Barang

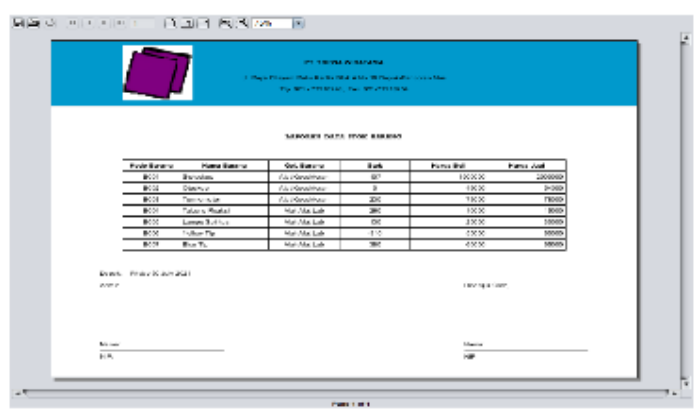

Gambar 14. Tampilan Layar Laporan Data Stok Barang

Gambar tersebut merupakan tampilan laporan data stok barang

Tampilan Laporan Data Pembelian

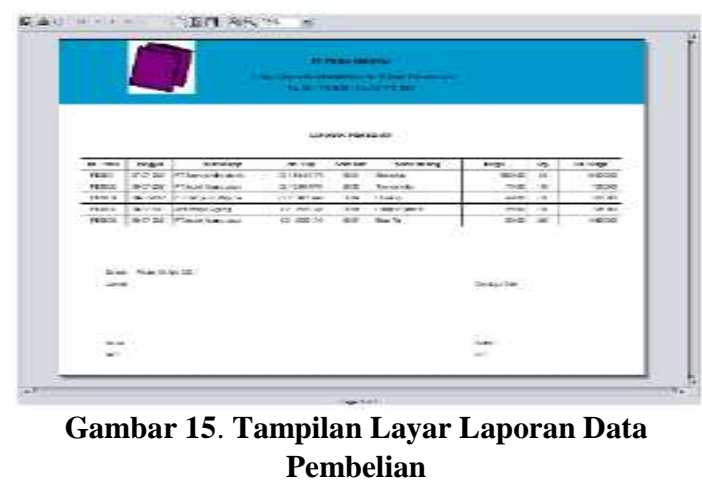

Gambar tersebut merupakan tampilan laporan data pembelian

Tampilan Laporan Data Penjualan

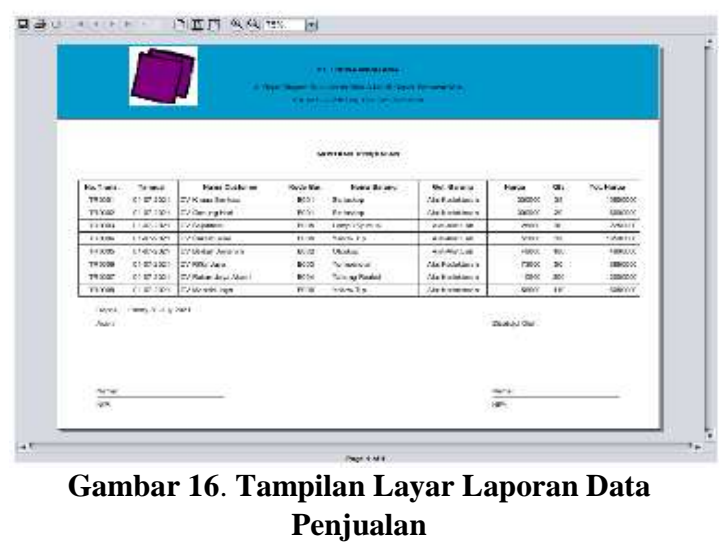

Gambar tersebut merupakan tampilan laporan data penjualan

\section{SIMPULAN DAN SARAN}

Dengan adanya sistem pengadaan dan penjualan alat kesehatan penjualan alat kesehatan pada PT. Trisna Wiratama akan menjadi lebih efisien dan dari hasil penulisan 
ini penulis menarik kesimpulan bahwa sistem pengolahan data yang sudah terkomputerisasi membuat kegiatan dalam pengadaan dan penjualan alat kesehatan lebih cepat dan rapih serta mendukung kinerja para karyawan lebih efektif dan efisien.

Adapun saran dari program aplikasi pengadaan dan penjualan ini adalah dibutuhkan pelatihan berkala terhadap karyawan yang akan terlibat menggunakan sistem ini. Diperlukan pemeliharaan sistem pengadaan dan apenjualan alat kesehatan secara berkala. Dibuatkan back up data sehingga data akan tersimpan, dari kerusakan yang berhubungan dengan faktor elektronik

\section{UCAPAN TERIMAKASIH}

Terima kasih kepada Pemimpin Perusahaan PT. Trisna Wiratama yang berkenan memberikan informasi mengenai perusahaannya dan pihak kampus Universitas Indraprasta PGRI atas terselengaranya penelitian ini dikarena tanpa adanya izin dari kedua belah pihak maka penelitian ini dapat terlaksana dengan baik dan terselesaikan dengan baik pula.

\section{DAFTAR PUSTAKA}

Aswati, D. (2015). Peranan Sistem Informasi dalam Perguruan Tinggi". Sumatra Utara:STMIK Royal Kisaran Sumatra Utara. Jurnal Teknologi dan Sistem Informasi. Vol.1 No.2.

Faruq, Z. H., Badri, C., \& Sodri, A. (2017). Penilaian Manajemen Peralatan Laboratorium Medis di RSUD Se Provinsi DKI Jakarta. Labora Medika.

Indarianto. (2013). Pengolahan Data Pelanggan dan Tagihan Laundry di Zam-Zam Laundry. Jakarta: Universitas Esa Unggul.

Islamiyah , Nur, R. A. dan A. O. (2018). Analisis Biaya Operasional dan Perputaran Persediaan terhadap Laba Bersih dengan Volume Penjualan sebagai Variabel Moderating. Journal Of Accounting, Vol. 4.

Ladjamudin, A.-B. Bin. (2013). Analisis dan Desain Sistem Informasi. Yogyakartya: Graha Ilmu.

Marbun, R. (2010). Tanya Jawab Seputar Pengadaan Barang/Jasa. Visi Media.

Nofriadi. (2015). Java Fundametal Dengan Netneans
Yogyakarta:DeePublish.

Suprihadi, Hudiono, R. K., \& Wijaya, L. S. (2013). Rancang Bangun Sistem Jejaring Klaster Berbasis Web Menggunakan Metode Model View Controller. CCIT Journal, 6(3).

Taufiq, R. (2013). Sistem Informasi Manajemen. Yogyakarta:Graha Ilmu. 